\title{
CHARACTERIZATION OF RHIZOBIA THAT NODULATE ARACHIS PINTOI BY RAPD ANALYSIS
}

\author{
Patrícia Pereira Pinto$^{1}$; Edilson Paiva²; Hortência Purcino ${ }^{3}$; Raul Vinícius Magalhães Passos ${ }^{1}$; Nadja Maria Horta Sá1* \\ ${ }^{1}$ Instituto de Ciências Biológicas, Universidade Federal de Minas Gerais, Belo Horizonte, MG, Brasil; ${ }^{2}$ EMBRAPA - Centro \\ Nacional de Pesquisa de Milho e Sorgo and ${ }^{3}$ EPAMIG, Fazenda Experimental Santa Rita, Belo Horizonte, MG, Brasil
}

Submitted: June 12, 2002; Returned to authors for corrections: April 03, 2003; Approved: June 30, 2004.

\begin{abstract}
The genetic relationships of 85 Arachis pintoi nodulating Rhizobium strains were determined using the random amplified polymorphic DNA (RAPD) methods. The analysis included 75 strains isolated from Cerrado soils and 10 other ones of different origins. The results indicated that there is a high level of similarity between these strains and that geographic distribution may affect their phylogenetic relationship. In addition, the results allowed the selection of the most suitable primers for characterisation of these Rhizobium strains which will be useful for implementation of competitiveness studies in Cerrado soils.
\end{abstract}

Key words: Rhizobium, Arachis pintoi, Cerrado soils.

\section{INTRODUCTION}

Pasture degradation in the Brazilian Savana (Cerrado) is mainly the result of predatory exploitation and/or inadequate management leading to loss of physical, chemical and biological soil properties (5). In an attempt to minimise this impact, several authors have discussed the beneficial contribution of forage legumes to soil fertility and to the increase in nutritive quality of forages $(9,14)$. Among the forage legumes indicated for Cerrado soils, the species Arachis pintoi has been suggested as one of the best alternatives because of its ability to adapt to, and persist in, these soils $(5,14)$. However, in spite of the positive contribution of this legume to the soil, the low number of rhizobial populations associated with A. pintoi in the soil (16) and the occurrence of inefficient native Rhizobium strains in the soils of tropical regions $(1,19)$, including Cerrado soils $(12,16)$, has limited the biological nitrogen fixation process in areas cultivated with this legume. Therefore, inoculation with selected Rhizobium strains is essential to increase the productivity of $A$. pintoi. In addition to the use of specific Rhizobium strains in the inoculation, it is fundamental to monitor the inoculated Rhizobium strains to ensure the success of the symbiosis process. Many methodologies used for this purpose have been described; however, the use of traditional methods such as serological studies or antibiotic resistance have been limited mainly by problems such as small size nodules, high frequency of antibiotic resistance and highly similar antigen structures (cross-reactivity) that usually occur among tropical Rhizobium strains $(3,15)$.

More recently, molecular techniques have been developed to provide reliable information on the diversity of Rhizobium populations in soils $(7,10,11)$. Among these techniques, genomic DNA fingerprinting using random amplification of polymorphic DNA (RAPD) has been shown to be useful to differentiate very closely related strains $(4,8,21)$.

In this study, characterization and evaluation of the genetic diversity of Rhizobium strains from different regions of the Cerrado that are able to associate with $A$. pinto $i$ were performed using genomic patterns obtained by RAPD. Afterwards the genetic groups (clusters) identified may give support to studies of persistence and competitiveness of these strains introduced into the field as inoculants.

\section{MATERIALS AND METHODS}

\section{Bacterial strains and growth conditions}

Seventy five of the 85 Rhizobium strains used in this study were isolated from A. pintoi (BRA031143) nodules collected

Corresponding author. Mailing address: Universidade Federal de Minas Gerais, Instituto de Ciências Biológicas, Departamento de Botânica, Pampulha. 31270-901, Belo Horizonte, MG, Brasil. FAX: (+5531) 499-2673. E-mail: nadja@mono.icb.ufmg.br 
from non inoculated plants cultivated in Cerrado soils from field or green house conditions. These strains are listed together with their origin, fertility and historical characteristics of the clay soils from which they were obtained (Table 1). The other strains were supplied by the Centro Internacional de Agricultura Tropical (CIAT), Colombia (CIAT2138, CIAT3101, CIAT3806) and by the North Carolina State University collection-USA (NC229, NC70, NC230, NC502.3, NC656, TAL295), and the strain indicated for the genus Arachis BR1405 was from the Centro Nacional de Pesquisa em Agrobiologia-Empresa Brasileira de Pesquisa Agropecuária (CNPAB-EMBRAPA). These strains were previously characterised according to their level of effectiveness with the homologous host and physiological characteristics of both fast and slow growth $(12,13)$. All the strains were grown in yeast mannitol medium (20) for three days at $29^{\circ} \mathrm{C}$ in an orbital shaker (200 rpm).

\section{DNA extraction and RAPD amplification}

Bacterial genomic DNA from each strain was extracted according to the methodology described by Sá et al. (15). Amplification reactions were performed with a Perkin-Elmer 9600 thermocycler. These reactions consisted of 40 cycles with each cycle including the following steps: denaturation at $94^{\circ} \mathrm{C}$ for 15 sec, annealing at $35^{\circ} \mathrm{C}$ for $30 \mathrm{sec}$ and elongation at $72^{\circ} \mathrm{C}$ for one min. An extra elongation step at $72^{\circ} \mathrm{C}$ for 7 min was performed after the last cycle. Each reaction mixture consisted of $25 \mathrm{~mL}$, with the following composition: 1X PCR buffer, $10 \mathrm{mM}$ of each dNTP (dATP, dTTP, dCTP and dGTP), $4 \mathrm{mM}$ of primer (Operon

Table 1. Rhizobium strains grouped according to their site of origin and chemical soil analysis of the isolation sites.

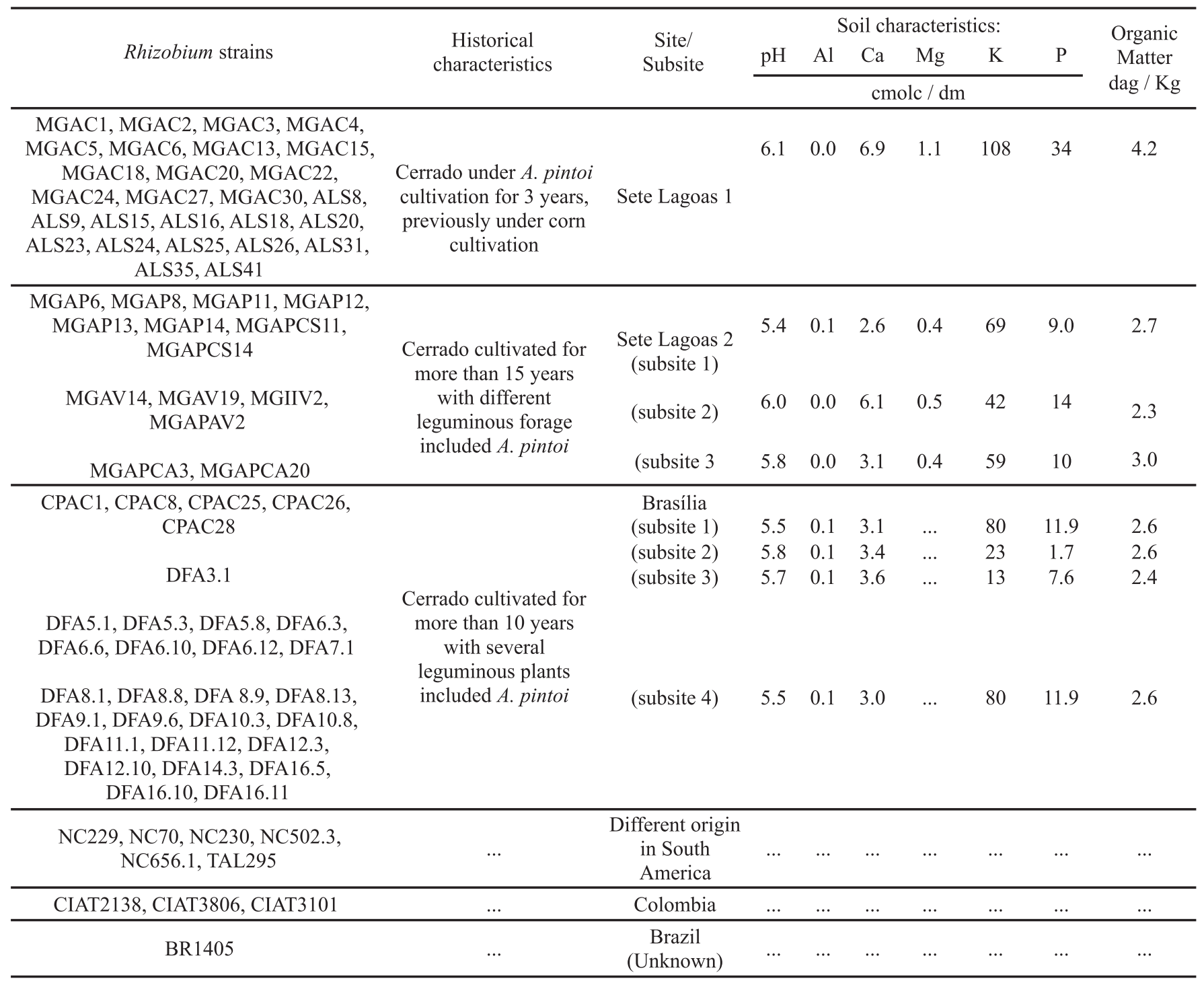


Technologies, Inc., Alameda, CA, USA), 1U Taq DNA polymerase and $25 \mathrm{ng}$ DNA sample. The samples were previously tested using 36 different primers, from which 14 that showed higher polymorphism were selected: OPC03 (CACTGGCCCA), OPC04 (ACGGGACCTG), OPC10 (AGCAGCGAGG), OPC19(AGTCC GCCTG), OPC20 (ACGGAAGTGG), OPA01 (AGACG GCTCC), OPA04 (AGGACTGCTC), OPA06 (GTGGGT GCCA), OPA09 (AGATGGGCAG), OPA10 (TGGTCGGGTG), OPE07 (GTG TCAGTGG), OPE10(CTGAAGCGCA),OPE11(AAGACCGGGA) and OPE15 (TGCCTGGACC). The amplification products were separated electrophoretically on 5\% acrylamide gels. The DNA bands were silver stained according to a methodology described by Santos et al. (17) and photographed.

\section{Data analysis}

Each analysis was a consensus of at least two replicates runs. The DNA bands were scored as 1 (present) or 0 (absent) and all intense and reproducible bands were considered. These data were used to determine the genetic distance between strains. Average linkage (UPGMA - unweighted pair group method with averages) dendrograms were produced using the Statistica program (CopyrightlSTASOFT Inc. 1993 - UNMN 06/74). The percentage of polymorphic products was calculated for every Rhizobium strain tested (8). The diversity index was calculated according to the equation: number of profiles/total number of strains described by Handley et al. (6) for each site, using the higher polymorphic primers (OPA10, OPA04, OPC03 and OPC10).

\section{RESULTS AND DISCUSSION}

The different primers used in this study yielded reproducible and polymorphic RAPD patterns for all the Rhizobium strains tested. Among these primers, OPA10, OPC10, OPA04 and OPC03 showed the highest polymorphism, with the percentage of polymorphic products ranging from $67 \%$ to $100 \%$, depending on the primer used and the site of origin of the Rhizobium. Most of the genotypes could be identified using one or two primers. Fig. 1 shows an example of the banding patterns obtained for some strains tested using the OPA10 primer. The amplification products varied in length from approximately 5090 to $298 \mathrm{bp}$. Based on variations in number and site of bands it was possible to identify individual strains. Despite the polymorphism observed with some primers, the diversity index was low, ranging from 0.19 to 0.37 according to the primer used and region of origin of the Rhizobium strains tested. The Sete Lagoas site showed the lowest index (Table 2). Analyis of RAPD fingerprinting data generated a dendrogram (Fig. 2) which suggested divisions based on genetic relationships between all of the strains evaluated. Low degrees of variation (9\% to 30\%) shown by linkage distance confirmed the trend in the diversity index obtained. In addition, it was possible to divide the strains into three clusters according to their site of origin. Two groups were formed with native Rhizobium strains from Sete Lagoas (1 and 2) and one with native Rhizobium strains from Brasília. The commercial strains from CIAT and the other strains of different origins were grouped within the Sete Lagoas 1 and Sete Lagoas 2 clusters, respectively. Analysis of physiological characteristics of the strains, such as growth rate and effectiveness previously determined $(12,13)$ were related with the groups generated by dendrograms. The majority of strains (75\%) were slow-growing (alcali producers) as a typical Bradyrhizobium strains and the remaining were fast-growing (acid producers). However this differential growth characteristic was not sufficient to distinguish groups in the generated dendrograms. Probably this behaviour

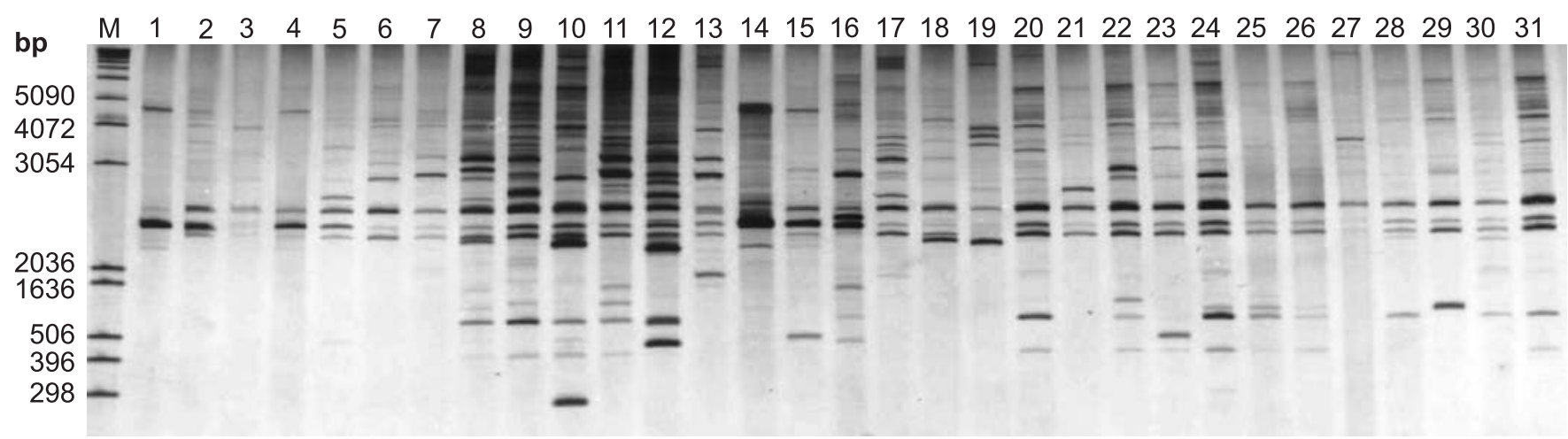

(M) marker $1 \mathrm{~Kb}$ Ladder; (1) CIAT3806; (2) CIAT3101; (3) CIAT2138; (4) BR105; (5) MGAC27; (6) MGAC15 (7) MGAC30; (8) MGAC22; (9) MGAC2; (10) MGAC13; (11) MGAC4; (12) MGAC5; (13) MGAC1; (14) MGAC6; (15) MGAC20; (16) MGAC18; (17) MGAC3; (18) MGAC24; (19) ALS18; (20) ALS16; (21) ALS8; (22) ALS43; (23) ALS25; (24) ALS9; (25) ALS15; (26) ALS20; (27)ALS31; (28)ALS24; (29)ALS35; (30)ALS23; (31)ALS26.

Figure 1. Example of RAPD banding patterns obtained for 31 Rhizobium strains associated with Arachis pintoi with primer OPA10. 
Table 2. Genetic diversity index (Handley et al., (6)) of the Rhizobium strains associated with A. pintoi from Sete Lagoas 1, Sete Lagoas 2 and Brasília sites, according to four different primers.

\begin{tabular}{cccc}
\hline \multirow{2}{*}{ Primer } & \multicolumn{3}{c}{ Origin site } \\
\cline { 2 - 4 } & Sete Lagoas 1 & Sete Lagoas 2 & Brasília \\
\hline OPA10 & 0.37 & 0.29 & 0.36 \\
OPC10 & 0.35 & 0.29 & 0.36 \\
OPA04 & 0.32 & 0.29 & 0.36 \\
OPC03 & 0.32 & 0.19 & 0.36 \\
\hline
\end{tabular}

represents more an adaptation of these strains to specific environmental conditions like micro niches with higher $\mathrm{pH}$ than of general soil conditions. Nevertheless these physiological differences may explain the polymorphism found among the analysed patterns. Similar results were found obtained by Mathan et al. (8) with strains isolated from Arachis hypogaea when studying these and other phenotypic characteristics. The relationship of strains effectiveness with groups generated by dendrogram showed higher number of effective strains in Sete Lagoas 1 cluster. However these differences may be explained by the presence of A. pintoi species in these site. According to many authors $(3,6,21)$ the specific host legumes species may favor the increase of rhizobia number, select the more effective and genetically more similar strains $(2,18)$ for each legume. The genetic variation within the groups Sete Lagoas 1 and Sete Lagoas 2 ranged from $11.6 \%$ to $25.5 \%$ and from $14 \%$ to $25.5 \%$, respectively, and within the Brasília group, from $9 \%$ to $28.5 \%$ (Fig. 2). The high similarity (approximately $70 \%$ ) found among the strains that are able to associate with $A$. pintoi is in accordance with several studies on genetic diversity of Bradyrhizobium populations which showed an elevated genetic homogeneity in this rhizobia group. Young and Cheng (21) compared similarities between Bradyrhizobium and Rhizobium from soybean cultivated in different tropical soils and found lower genetic variation in Bradyrhizobium than in Rhizobium. Strains isolated from Arachis hypogaea in Indian soils were also found to be a homogeneous Rhizobium group (8). In addition to that, the presence of $A$. pintoi in origin sites of the strains and the use of only one ecotype (BRA031143) as trap host may favor the selection of genetic similar strains.

The three clusters established by the analysed strains indicated the influence of environmental conditions or soil characteristics on the genetic distribution of these rhizobia. The physical-chemical characteristics of the soils are shown in Table 1. In Sete Lagoas 1 higher levels of organic matter, nutrients and $\mathrm{pH}$ values were observed. In contrast, the soils from Sete Lagoas 2 and Brasilia subsites had more homogeneous characteristics and lower organic matter and nutrient levels and $\mathrm{pH}$ values. These discriminating characteristics (organic matter and nutrients) seem to be acting as

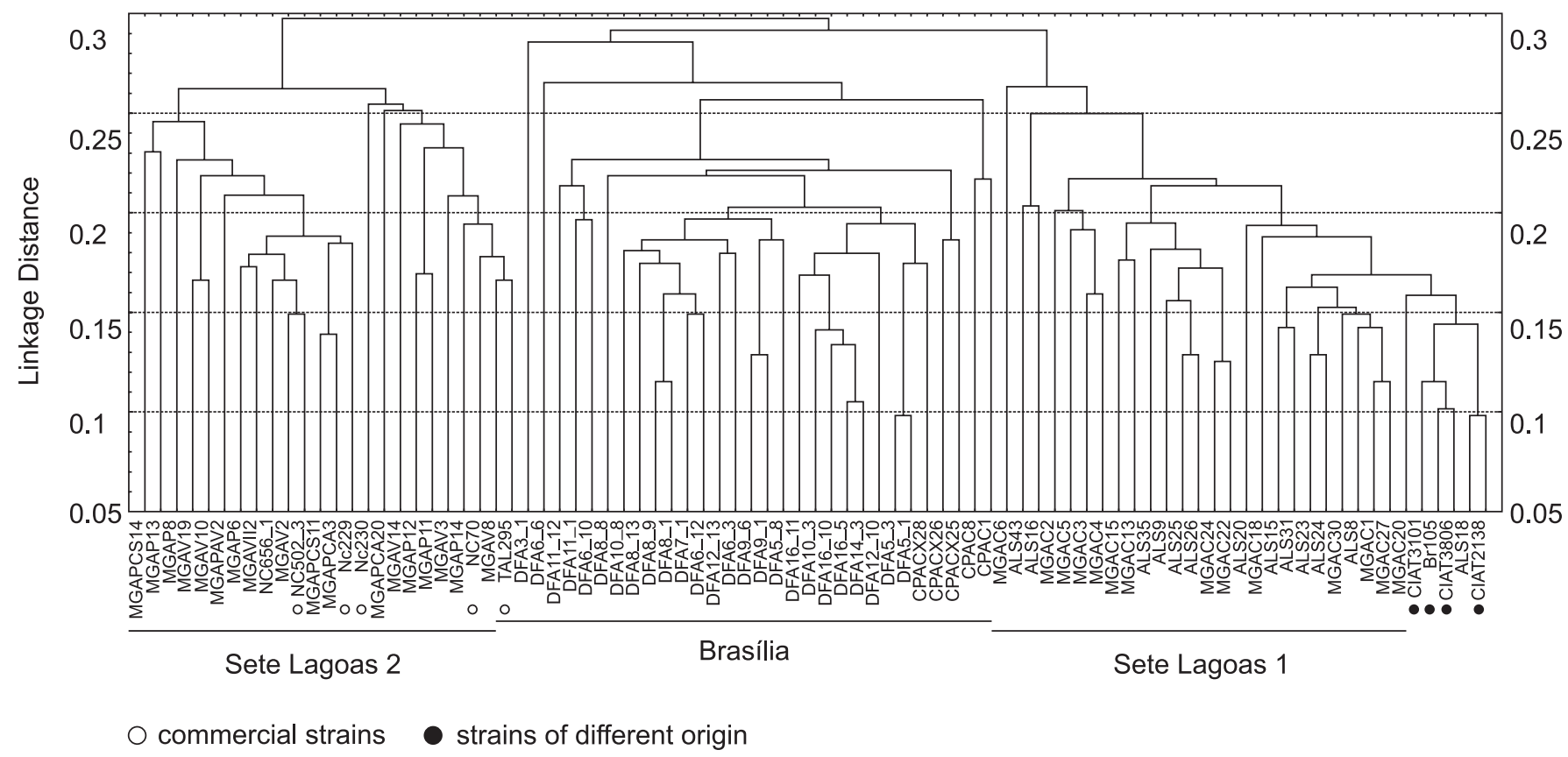

Figure 2. Dendrogram showing the genetic relationship between 85 Rhizobium strains associated with A. pintoi, by RAPD analysis, using 14 different primers. 
a selective pressure for grouping closely related strains, but did not appear to influence the diversity index of rhizobia. Similar results were obtained in studies conducted on different species of rhizobia $(4,6,8,21)$. These reports indicated the direct influence of the site on the grouping of the strains investigated.

In spite of the high genetic homogeneity observed among the rhizobia strains associated with A. pintoi in Cerrado soils, RAPD analyses identified adequate primers for the characterisation of strains as demonstrated with OPA10 (Fig. 1 ). In addition, the results of this study confirm that PCR is a useful tool for phylogenetic and ecological investigations of rhizobial communities and will also permit to conduct competitiveness and persistence studies on these rhizobia strains when inoculated in Cerrado soil as inoculants.

\section{ACKNOWLEDGMENTS}

This work was supported by FAPEMIG.

\section{RESUMO}

\section{Caracterização de rizóbios capazes de nodular Arachis pintoi via análise de "RAPD"}

As relações genéticas de 85 estirpes de Rhizobium capazes de nodular Arachis pintoi foram determinadas usando o método de "RAPD" (Random Amplified Polymorphic DNA). As análises incluíram 75 estirpes isoladas de solos de Cerrado e 10 de diferentes origens. Os resultados indicaram que existe um alto grau de similaridade entre estas estirpes e que a distribuição geográfica pode afetar suas relações filogenéticas. Além disso, os resultados permitiram a seleção de "primers" mais adequados para a caracterização dessas estirpes de Rhizobium, os quais serão úteis para a implementação de estudos de competitividade nos solos de Cerrado.

Palavras-chave: Rhizobium, Arachis pintoi, solos de Cerrado.

\section{REFERENCES}

1. Bahnisch, G.A.; Date, R.A.; Brandon, N.J.; Pittaway, P. Growth responses of Desmanthus virgatus to inoculation with Rhizobium strain CB3126. I. A pot trial with 8 clay soils from central and southern Queensland. Trop. Grassl., 32:13-19, 1998.

2. Coutinho, H.L.C.; Oliveira, V.M.; Lovato, A.; Maia, A.H.N.; Manfio, G.P. Evaluation of the diversity of rhizobia in Brazilian agricultura soils cultivated with soybeans. Appl. Soil Ecol., 13:159-167, 1999.

3. Fettell, N.A.; O'connor, G.E.; Carpenter, D.J.; Evans, J.; Bamflorth, I.; Oti-Boateng, C.; Hebb, D.M.; Brockwell, J. Nodulation studies on legumes exotic to Australia: the influence os soil populations and inocula of Rhizobium leguminosarum bv. viciae on nodulation and nitrgen fixation by field peas. Appl. Soil Ecol., 5:197-210, 1997.
4. Frémont, M.; Prin, Y.; Chauviére, M.; Diem, H.G.; Pwee, K.H.; Tan, T.K. A comparison of Bradyrhizobium strains using molecular, cultural and field studies. Plant Sci, 141:81-91, 1999.

5. González, M.S.; Van Heurch, L.M.; Romero, F.; Pezo, D.A.; Argel, P.J. Producción de leche en pasturas de estrella africana (Cynodom nlemfuensis) solo y associado com A. pintoi o Desmodium ovalifolium. Pasturas Trop., 8(1):2-12, 1996.

6. Handley, B.A.; Hedges, A.J.; Beringer, J.E. Importance of host plants for detecting the population diversity of Rhizobium leguminosarum biovar viciae in soil. Soil Biol. Biochem., 30(2):241-249, 1998.

7. Laguerre, G.; Mavingui, P.; Allard, Marie-Reine; Charnay, MariePaule; Louvrier, P.; Mazurier, Sylvie-Isabelle; Rigottier-Gois, L.; Amarger, N. Typing of Rhizobia by PCR DNA Fingerprinting Analysis of Chromosomal and Symbiotic Gene Regions: Application to Rhizobium leguminosarum and Its Different Biovars. Appl. Environ. Microbiol, 62(6):2029-2036, 1996.

8. Mathan, M.; Parani, M.; Parida, A.; Nair, S. Random amplified polymorphic DNA analysis of root-nodulating bacterial strains from Arachis hypogaea with physiological characteristics of both fast and slow growers. Lett. Appl. Microbiol., 23:89-92, 1996.

9. Minson, D.J.; Cowan, T.; Havilah, E. Northern dairy feedbase (2001). 1. Summer pasture and crops. Trop. Grassl., 27: 131-149, 1993.

10. Oliveira, I.R.; Vasconcellos, M.J.; Seldin, L.; Paiva, E.; Vargas, M.A.; Sá, N.M.H. Random amplified polymorphic DNA analysis of effective Rhizobium sp. associated with beans cultivated in Brazil cerrado soils. Braz. J. Microbiol., 31:39-44, 2000.

11. Pinto, P.P.; Raposeiras, R.; Macedo, A.M.; Seldin, L.; Paiva, E.; Sá, N.M.H. Effects high teperature on survival, symbiotic performance and genomic modifications of bean nodulating Rhizobium strains. Rev. Microbiol., 29:295-300, 1998.

12. Pinto, P.P.; Carneiro, J.A.; Vargas, M.A.T.; Purcino, H.A.; Sá, N.M.H. Indigenous rhizobia associated with Arachis pintoi in Cerrado soils of Brazil. Pasturas Trop., 21(2):25-28, 1999.

13. Pinto. P.P. Ocorrência, eficiência de fixação de nitrogênio e variabilidade genética de estirpes de rizóbio associadas ao Arachis pintoi em solos de Cerrado. Belo Horizonte, 2000, 93p. (Dissertação de mestrado. Instituto de Ciências Biológicas. UFMG).

14. Purcino H.M.; Viana M.C.A.; Botelho W.; Zúñiga M.C. Introdução e avaliação de ecótipos de gramíneas e leguminosas em área de Cerrado virgem de Minas Gerais, Brasil. Pasturas Trop., 19(1):21-26, 1997.

15. Sá, N.M.H.;Scotti, M.R.M.L.; Vargas, M.AT.; Dobereiner, J. Resistência natural a estreptomicina e eficiência de estirpes de rhizobium nativas nos Cerrados, associadas a Stylosanthes. Pesqui. Agropecu. Brás.. Brasília, 18(3):213-218, 1983.

16. Sá, N.M.H.; Pinto, P.P.; Passos, R.V.M.; Carvalho, J.G.; Vargas, M.A.T.; Purcino, H.A. Seasonal Dynamic of Native Rhizobial Populations Associated with A. pintoi in Cerrado Soils. Pasturas Trop., 23(1):29-31, 2001.

17. Santos, F.R.; Pena, S.D.J.; Eppelen, J.T. Genetic and population study of a Y-linked tetranucleotide repeat DNA polymorphism with a simple non-isotpic technic. Hum. Genet., 90:655-656, 1993.

18. Saleena, L.M.; Loganethan, P.; Rangarajan, S.; Nair, S. Genetic diversity and relationship between Bradyrhizobium strains isolated from blackgran and cowpea. Biol. Fértil. Soils, 34:276-281, 2001.

19. Vargas, M.A.T.; Suhet, A.R.; Mendes, I.C.; Peres, J.R. Fixação biológica de nitrogênio em solos de Cerrados. [Planaltina, DF] EMBRAPA-CPAC/Brasília, 1994, 83p.

20. Vincent, J.M. A manual for The practical study at root-nodule bacteria. Oxford, Blackwell, 1970, 164p.

21. Young, C.C.; Cheng, K.T. Genetic diversity of fast-and slow-growing soybean rhizobia determined by random amplified polymorphic DNA analysis. Biol. Fertil. Soils, 26:254-256, 1998. 